\title{
Investigation of Defects of Article 264 of Iranian Civil Code
}

\author{
Mehdi Pirhaji ${ }^{1}$, Sakina Shaik Ahmad Yusoff ${ }^{1}$, Suzanna Mohamed Isa ${ }^{1} \&$ Mahmoud Jalali ${ }^{2}$ \\ ${ }^{1}$ Faculty of Law, Universiti Kebangsaan Malaysia, Bangi, Selangor, Malaysia \\ ${ }^{2}$ Department of Law, University of Isfahan, Isfahan, Iran \\ Correspondence: Sakina Shaik Ahmad Yusoff, Faculty of Law, Universiti Kebangsaan Malaysia, Bangi, Selangor, \\ Malaysia. Tel: 60-19-273-5798. E-mail: kinasay@ukm.my
}

Received: September 3, 2013 Accepted: January 14, 2014 Online Published: March 31, 2014

doi:10.5539/ass.v10n7p38 URL: http://dx.doi.org/10.5539/ass.v10n7p38

\begin{abstract}
Discharge of contractual obligations is one of the most important issues in (Iranian) contract law, and Articles 264 to 300 of Iranian Civil Code are devoted to this issue. Inappropriate combination of Islamic Sharia with French law causes some ambiguities in Articles 264 to 300 of the Iranian Civil Code. Moreover, the Iranian legislator has not offered definitions for some factors of discharge of obligations such as fulfilment of obligation, substitution of the obligation, and set off and recoupment. The Iranian legislator has not even mentioned on what basis it has obtained the present categorization for six factors of discharge of obligations, namely: fulfillment of obligation, cancellation of a contract by mutual consent, release from obligation, substitution of a different obligation, offset and recoupment and by acquisition of the debt. This paper exclusively aims to examine, criticize and discuss the problems arising from the Article 264 of the Iranian Civil Code. In this study, the data gathered is of the library type and the research method is both analytical and critical.
\end{abstract}

Keywords: contract, discharge, agreement, obligation, civil code, legal system, Iran

\section{Introduction}

The Civil Code of Iran is the backbone of its legal system. The criteria, standards, and verdicts of Civil Code flow, like blood, in all parts of the body of Iranian legal organizations or its legal system and the monumental duty of being the heart of this body is on the Civil Code. That is why great attention has been given to the codification of the Civil Code. The legislator enjoys the assistance of legal experts who are familiar with all legal concepts and a criterion as well as the values of the Iranian society (Langroodi, 2009). Law is the art of just organizing people's relationships. In this regard, there is no need to say how important the Law, obligation and contracts are. Everyone in his social life is inevitable to conclude some contracts or he may undertake civil responsibility due to the damages caused to the other.

Most of the sections of the Iranian Civil Code are shaped according to the structure of French Civil Code; thus, how the contractual law in Iran is affected by the Islamic Law and Roman-Germanic law will be discussed in this paper and then each problem will be criticized separately (Katouzian, 1997). Deep analysis of Article 264 and the necessity of providing a new theory made us argue and criticize the causes of discharge of obligations in Iran. In Article 264 of Civil Code, Iranian legislator has just mentioned causes and factors for discharge of obligation, not providing any definition of discharge of obligation or classification of the causes. As a result, Articles 264 to 300 of Civil Code of Iran have some defects (Ghasemzadeh, 2009). The obligation that is under the responsibility of the person is not eternal and will be terminated one day and this truth is more apparent in financial relations resulting from contact or civil responsibility.

In Iran, "obligation" section constitutes the main part of Civil Code, and discharge of obligation as well as its causes are stipulated in Article 264 of Civil Code (Shahidi, 2008).Iranian legislator has imitated the structure of French Civil Code and made some modifications in it and by stating Article 1234 of French Civil Code provided its own theory. However, apart from some negligible discrepancies, most of the Iranian lawyers have pointed out the problems arising from Article 264 and accepted that this Article needs to be refined. Undoubtedly, the foundation of Civil Code of Iran is, in form, similar to French Civil Code but in content is organized according to the Islamic law. In Islamic Law, the discharge of obligation is not considered as a distinct part; thus, the issues of discharge of obligation can be extracted from other chapters of Islamic law, such as sale, debt, mortgage, lessor, guarantee, draft, suretyship, donation, marriage and divorce (Shahidi, 2011). 
The Article 264 Civil Code of Iran states that obligations are discharged in one of the following six ways namely 1) by fulfillment of obligation, 2) by cancellation of a contract by mutual consent, 3) by release from obligation, 4) by substitution of a different obligation, 5) by offset and recoupment and 6) by acquisition of the debt (Bonakdar,2005).Therefore, Iran legislator has mentioned six causes for discharge of obligation, whereas there are nine causes of discharge in Article 1234 French Civil Code. What has been discovered from inspecting the problems in this Article is that the Article 264 of Iran Civil Code must be reformed. This paper solely identifies, criticizes and discusses the problems arising from the Article 264 of Iranian Civil Code.

It is evident that contract is concluded at a time, but it is not permanent and will be terminated one day. How a contract is discharged is one of the most important issues which has received great attention in all legal systems. Inappropriate combination of Islamic Sharia with French or Roman-Germanic law has caused some ambiguities in Articles 264 to 300 of Iran Civil Code. Unsuccessful integration of the causes of discharge of obligation and not providing an appropriate classification and perfect definition for these causes are among the problems arising from Article 264 Civil Code of Iran. The main purpose of criticizing and analysing is to investigate the defects of Article 264 and identify legal system and discharge of contract law in Iran.In this study, the data gathered is of the library type and the research method is both analytical and critical (Yaqin, 2007).

\section{Problems Arising from Article 264 Civil Code of Iran}

\subsection{Inappropriate Combination of Islamic Law and French Civil Code}

Civil Code is one of the main branches of private law which investigates and formulates the relationship of people with each other in a society, regardless of their social status and position (Collins, 2010).The term Civil Code has been derived from the "Juris Civilis" in Roman law. After the fall of Roman Empire, public rights became obsolete and useless; thus, everybody who talks about the Civil Code or Roman law means private law of Rome which was imitated by many other countries including France (Javan-arasteh, 2009). After French Revolution in 1789, the term Civil Code was substituted for private law. In Iran, following their familiarization with culture and civilization of France, law codifiers codified Iran Civil Code in 1928. Civil Code just investigates the relationships between people in society and does not care about the characteristics of different jobs. People, property and family are the main concerns of Civil Code (Harisinejad, 2009). In one glance, it can be said that Civil Code is the rights and status of people and their affiliates regarding family or financial affairs. Generally, it can be divided into four main categories namely (i) entities and family, (ii) Ownership, (iii) contract and civil liability, and (iv) heritage.

Resources of Civil Code in each country, whatever their legal style would be, include statute, custom, judicial precedent and ideas of legal scholars (Shiravi, 2010). Law is the most important source of Civil Code and the regulations pertaining to Civil Code should be found in Law. Iran Civil Code includes 1335 Articles compiled in three volumes. The first volume includes 955 Articles and was passed in 1928. The second volume, from Articles 956 to 1256, and the last volume, from Article 1257 to 1335, were passed in 1934. The first volume uses Islamic jurisprudence; however, in some cases, the Law of Belgium, France and Switzerland have been used in the second and third volumes. Some modifications had been made in Civil Code of Iran especially after the Iranian revolutionin 1979 (Hamiti-vaghef, 2009).

The Civil Code of each country is the backbone of legal system of that country, on which all the contractual and non-contractual relationships of that society are based (Madani, 2004). Codifiers of Iran Civil Code have adapted its first volume from two basic sources: Islamic Law and French Civil Code. The impact of these two sources on Iran Civil Code has caused that the interpreters and judicial experts face some ambiguities in interpreting some Articles of Civil Code and consequently made it inevitable for them to refer directly to Islamic Law and French Civil Code. Articles 245 to 300 Civil Code of Iran are concerning the discharge of obligation in which both Islamic and French Law are manifested. Despite passing many years since their approval, these Articles continued to be discussed (Katouzian, 2008).

The most important section of Iranian Civil Code is obligation right and the codifiers of Iran Civil Code have adapted the chapters of agreement and obligations from French Civil Code in such a way that most of the Articles in this chapter are the translation of the corresponding Articles in French Civil Code. These translations have been done by some members of Civil Code Codification Committee, who have studied law in Europe. Then, the translated Articles were passed to other committee members who were mostly Islamic jurists and Islamic Law scientists. These jurists and scholars formulated the Articles according to the Islamic standards and jurisprudence. Moreover, in this translation, the combination and selection of some Articles of French Civil Code which was the main source for the codifiers of Iran Civil Code were pointed out in footnotes. However, what is evident is that the integration of Civil Code has not been without any deficiencies or shortages though the 
art of combining and selecting Articles has been sometimes associated with the creativity of lawyers and codifiers of Iranian Civil Code.

Therefore, secularizing judicial system and promotion of nationalism were their basic principles (Katouzian, 2008). The consequence of governance of secularism was divesting the clergymen of their influence and authority. During this period clergymen were, to a large extent, removed from judicial positions, education, and cultural affairs. By performing the rule of wearing uniform, most of the clergymen had to be defrocked and seminary courses lost their boom. Reza Shah Pahlavi put an end on the influence of clergymen in judicial affairs and removed them from important positions. It is noteworthy that Reza Shah's measures caused the governance of Shariah rules to be vanished. The basis of the evolutions in this period was Ali AkbarDavar'sefforts in Administration of Justice in such a way that it caused basic changes in this ministry.Due to his authorities, Davar founded the new judicial system in Iran and made the rules close to those of the west. The important issue in codifying Iran Civil Code is that why the judicial system of Iran set up to adapt the European laws and how this has been done (Zarrini, 2009). Understanding this historical background will helps us to better realize the problems arising from Article 264 of Iranian Civil Code.

Following the governance of Pahlavi Regime in Iran, Iran legal system entered a new era since the Constitutional revolution evolved and got new appearance. Reza Shah was the first king of Pahlavi Regime who came to power in November 1925. Qajar dynasty was overthrown in 1926. Reza Shah was not an educated and literate man, but due to the conditions of the world in that era, he was inevitable to make some changes in the traditional style of governance. In thatera, Iran underwent a lot of changes (Zarrini, 2009). After consolidating his power, Reza Shah did his best to eliminate the influence of clergymen. His long-term purpose was to create quasi-western society the ideological basis of which was secularism.

Although adapting the form of French Civil Code, Iran legislator has taken into account the content of Shariah in codifying Civil Code. This has made the legislator select some Articles on discharge of obligation from French Civil Code and add the "cancellation of contract by mutual consent" to Article 264. In his book entitled "The Development and Discharge of Obligations in Islamic Law", he has mentioned 13 causes of discharge of obligation and has added the following causes to Article 264 including destruction of property, impossibility of performance, lapse of time, revocation, divorce, donation, expiration of time, and damages (Aliabadi, 2009).

The cancellation of a contract by mutual consent literally means removal. In legal parlance, this means the agreement of the contracting parties on the dissolution of the relevant contract. Articles 283 to 288 of the Iranian Civil Code are devoted to the cancellation of contract by mutual consent. Since the cancellation of contract by mutual consent was adopted by Iranian legislators directly from Sharia and Islamic texts, and merged with the causes of discharge of obligation, its foundation does not lie entirely in the French Civil Code. In Islamic texts and strictures, the cancellation of contract by mutual consent is used only in financial contracts, and not in non-financial ones, such as marriage contracts. For example, under Article 1120 of the Iranian Civil Code, the dissolution of a marriage contract is possible only by the termination of the marriage, and divorce (Shahidi, 2011). Therefore, cancellation of contract by mutual consent is applicable only to certain forms of contracts (financial), but not to others (non-financial).

Even in a case involving pious endowment, which is one of the important forms of Islamic contracts, the cancellation of contract by mutual consent is impossible, because in such a cancellation, the mutual consent of the contracting parties is essential, and the endowed property doe not have a specific owner. A key question that arises in this connection is why Iranian legislators chose to include the cancellation of contracts by mutual consent among the causes of discharge of obligation. It seems here that the principal contract, and the agreement to cancel, has been conflated, whereas there is a clear difference between both concepts. Obligation is a commitment or responsibility arising from an agreement, but not the agreement itself (Bagheri, 2003). It is precisely for this reason that the cancellation of contract by mutual consent has not been included in the Egyptian law of obligation whose legal foundation is similar to that of Iran, Switzerland, and France (Nouri, 2001).

In Islamic law, the discharge of obligation is not a distinct subject category standing independently on its own. Instead, issues relating to it are to be extracted from other chapters of Sharia, such as sale, liability, mortgage, lessor, civil liability, draft, suretyship, donation, marriage, divorce, expiration, will, damages, destruction of property, impossibility of performance and revocation (Bahrami-Ahmadi, 2007). While each of the six causes of discharge of obligation stipulated in Article 264 of the Iranian Civil Code may indicate some creativity on the part of the codifiers, they have, unfortunately, not been quite successful in their task. If all the direct causes of discharge of obligation are to be integrated into a collection, the fulfilment of obligation must also be included in such a collection. Moreover, if cancellation by mutual consent is a cause of discharge, then questions must be 
asked as to why the revocation of contract is not included among the causes of discharge of obligation in the Iranian Civil Code.

Furthermore, although death or the loss of the subject matter of obligation can be a cause of discharge of obligation, none of them is mentioned in Article 264 of the Iranian Civil Code. All of these render more apparent the absurdity in seeking to combine the causes of discharge of obligation in Islamic law with those of the French Civil Code. The result is that Article 264 has attracted critical comments, in terms of both its content and form, from those who believe that the Article has failed to cover all the legal requirements for the discharge of contractual obligations under Sharia (Bagheri, 2003). Thus, it is argued that this combination is not exactly consistent with Sharia requirements. While the observed shortcomings should not prevent us from appreciating the efforts of the drafters of the Civil Code in their bid to align it with Islamic law and principles, critiquing the causes of discharge of obligation in private law can be an important step in the quest for novel methods of legal interpretation.

\subsection{The Problem of Classification and Definition}

\subsubsection{Improper Classification}

The drafters of the Iranian Civil Code adopted the causes of discharge of obligation from Article 1234 of the French Civil Code. In doing so, however, they excluded 4 causes of discharge found in the French Civil Code (loss of the object of obligation, termination or revocation of contract, fulfilment of dissolution condition, and lapse of time), and added the cancellation of contract by mutual consent. The result is the classification of the causes of discharge of obligation contained in Article 264 of the Iranian Civil Code. This, however, is not a complete classification because some other causes can also be included, such as impossibility of performance, or lapse of time. Additionally, a review of Articles 264 to 300 would reveal that some Articles are bereft of definitions. As would be explained subsequently in this article, that lacuna has resulted in ambiguities. Just as the products of the modern industrial society are complex and mysterious, so are legal issues, which are often an admixture of the complex and the trivial. For example, it is not possible to unveil the mystery underlying the combination of sound and image transmitted to viewers through a television set, without first analysing the interaction between the form (trivial) and the content (essential), in order to decipher the relation. So it is with the law. For example, imposing obligation for the destroyed object of sale on the seller would seem superficial and irrational without initially decomposing the problem into its simpler elements, and then subjecting them to a systematic analysis.

Conclusion and advantages of the discussion: Legal issues, although often apparently simple, are, in reality, very technical and complicated. As noted already, Iranian legislators adopted the classification of the causes of the discharge of obligation in Article 1234 of the French Civil Code, omitted some of the causes stipulated therein, and came up with an Article 264 that contains only six causes of the discharge of obligation. This is not without problems (Safaei, 2008). By following such an approach, Iranian legislators made a faulty induction, in the process creating several problems with regard to both the form and the content of Article 264. Combining the concepts of contract and obligation is equally problematic because that constitutes the substitution of obligation as one of the causes of discharge of obligation, whereas substitution is the change of obligation, not the discharge of it.

The use by Iranian legislators of the term "cancellation of contract by mutual consent," which is the same thing in content as the performance of obligation, reveals the defect of Article 264 of the Iranian Civil Code. Indeed, Articles 264 to 300 of the Code are frustrating to analysts. Some Articles suffer from lack of definitional clarity, while others contain no definitions at all. This has led to ambiguities, resulting in the conflicting interpretations given by the Iranian courts. For example, Article 183 of the Code, which defines a contract, states that "a contract is made when one or more persons make a mutual agreement with another one or more person, on a certain thing, and that agreement is accepted by the latter person(s)."

But there are evident differences among lawyers and Islamic jurists with regard to that definition; Islamic jurists have never proffered an absolute definition of a contract; the only definition they have provided is limited in nature. Perhaps, this explains why they did not see any need to provide an absolute definition. (Note 1)

It should be observed that the definition provided in Article 183 of the Iranian Civil Code is more general than the one provided by Islamic jurists. That definition does not conform the one provided by Islamic jurists. It should also be remembered that there are differences between an obligation and a contract. Obligation is a personal (debt-based) relation between a debtor and a creditor. This relation is sometimes created by contract, but at other times, arises due to certain events like civil liability. Therefore, although a contract may result in the creation of an obligation, the existence of this causal relationship should not lead to the combination of the cause 
and the effect, since the consequence of a contract cannot be limited to the creation of an obligation.

The consequence of a contract is sometimes the creation of a jus in rem. The provisions of Article 183 of the Iranian Civil Code were emulated from Article 1101 of the French Civil Code, and were formulated based on this foreign thought (Mirzaee, 2009). However, in Islamic law, the consequence of a contract regarding the passing of ownership from one party to another, is also considered. It is not limited to the creation of an obligation. Contract, in Islam, is the means of creating an obligation, possession, and a debt right.

For example, Article 140 of the Iranian Civil Code includes contracts among the means of creating possession, which shows that contracts are not limited to the creation of obligation (katouzian, 2006). Therefore, if the drafters of the Iranian Civil Code did not repeat the mistake made by the French, and took into consideration, linguistic differences, and Islamic rights in their definition of a contract, they would not have faced difficulties. As indicated earlier, a contract often leads to the creation of jus in rem, instead of an obligation or a debt right. And at other times, it leads to the transfer, or the discharge of an obligation in relation to the jus in rem, and is not limited to the creation of an obligation.

Clause 1 of Article 264 of the Iranian Civil Code is about the fulfilment of obligation. Fulfilling the obligation, performing the obligation, paying the debt, and executing the obligation, are all equivalent. There are heated arguments over the ways of fulfilling an obligation, and in the law of some countries such as Iran, Egypt and France, the fulfilment of an obligation is not defined. Islamic jurists have also not provided a definition for the term, even though they have used it in their arguments (Aliabadi, 2009).

In common law, the fulfilment of obligation is provided for under the name of performance, and includes performing the obligations resulting from the contract, or any other obligations, by the obligor to whom the consequences of the breach of contract will be attached (Ahmadi, 2007). Sometimes, the fulfilment of obligation is defined by its consequences. Such a definition encompasses the discharge of the obligation and some of its attributes and specifications.

Instead of the discharge of obligations, other synonyms are also used. For example, fulfilment of obligation could mean performing it, attending to the obligation and promise, and terminating the promise. Therefore, fulfilment of obligation means performing the relevant promise. Other terms such as paying the debt, and performing the obligation can also be used in its place. The word obligation also means promise, oath, covenant and condition. Based on the different definitions provided in legal texts, the fulfilment of obligation could be characterised in this following manner:

1) Fulfilment of obligation causes the clearance of the obligor and their discharge from obligation.

2) It makes no difference whether the cause of obligation is a unilateral legal act, a contract, or any other thing.

3) Fulfilment of obligation consists of either an intentional and voluntary performance of the obligation, or the compulsory and forcible performance of it.

Therefore, in defining the fulfilment of obligation, it can be said to consists in the obligor acting in accordance with the obligation. Clause 2 of Article 264 of the Iranian Civil Code refers to the cancellation of contract by mutual consent, but does not provide any definition for that term. "Cancellation" means removing or cancelling something, and is used when the cancellation of a sale, or generally, the cancellation of a contract is intended. In effect, it means releasing the contract. In Arabic, "cancellation" means releasing a person from something from which he suffers. In Islamic law parlance, "cancellation" means cancellation of contract by the mutual consent of the parties involved (Langroodi, 2010). Lawyers influenced by Islamic jurists, define the "cancellation" of contract as the mutual consent on the part of two parties to cancel the contract.

As can be seen, the main substance of cancellation is the mutual consent of the parties, and because of this, it is interpreted as "cancellation" (Hashemi, 2004). Cancellation generally terminates a contract. In other words, the primary purpose of cancellation is to bring a contract to an end, and of which the discharge of obligation is an essential part. Cancellation of contract by mutual consent is possible only when there is already a contract in existence whose consequences the parties intend to terminate. In this regard, the cancellation will have the same effect as a discharge. As a discharge is not possible unless a debt already exists, so is cancellation impossible unless there has already been a contract. (Bagheri, 2003). Clause 3 of Article 264 of the Iranian Civil Code refers to discharge, which is defined in Article 289 of the Code.

Discharging the right a person has against someone else is called release. Of course, this is a debt right, and the jus in rem is known as a waiver. In his Terminology of Law, Langroodi defines release as a creditor's intentional waiver of his debt. (Langroodi, 2010) Discharge, literally means releasing from the other, or from something, which is with a person, but who has no desire for it. In an Islamic juristic sense, discharge means discharging 
what one owes to another person. In Article 289 of the Iranian Civil Code, discharge is defined as a creditor's intentional waiver of his right.

Clause 4 of Article 264 of the Iranian Civil Code points to the substitution of obligation, but does not define it. However, substitution of obligation, as the term implies, means substituting a new obligation through the removal of past debts by virtue of which an obligation is discharged, and another one is simultaneously created. Hence, Iranian legislators included it among the causes of discharge of obligation. In other words, the notion of substitution of obligation has been established in order to integrate two legal acts; to create a legal relationship between parties and to simplify the process of changing that relationship. Thus, instead of discharging an obligation in one distinct act, and then creating another one in a new legal act, the contracting parties can simultaneously discharge an obligation by mutual consent, and replace it with a new one. Historically, substitution of obligation can be traced back to ancient Roman law.

In a nutshell, then, substitution of obligation can be defined as the replacement of an existing obligation with another one so that the existing obligation is discharged, and a new one created. In the French Civil Code, Articles 1271 to 1281 govern the substitution of obligation, and Article 1271, in particular, was adopted by the drafters of the Iranian Civil Code in formulating Article 292 thereof (Shahidi, 2011).

It should be kept in mind that the substitution of obligation in modern law is substantially different from what it was under ancient Roman law. In the law of ancient Rome, since there was no provision for the transfer of debt, the substitution of obligation inevitably had to be conceived in order to fill this vacuum. By contrast, in modern law, the instruments of draft and contractual guarantee are used as the means of transferring debt, instead of substitution. Thus, the former can be considered as one of the causes of discharge of obligation (Bagheri, 2003).

Clause 5 of Article 264 of the Iranian Civil Code refers to "offset" as the fifth cause of discharge of obligation, and devotes Articles 294 to 299 to this issue. But it does not provide a distinct definition for the term. Nonetheless, offset may be taken to mean the discharge of debts two parties mutually owe to each other. In its literal sense, offset means disaster, slip, or errors in speech, the cancellation of legal claims made by parties against each other, and barter. But in a strict legal sense, it means giving up a debt owed by the one party to the other. In legal texts, offset is divided into three types: obligatory, contractual and judicial. It is a means of discharging an obligation. It prevents the repeated payment of a debt, and reduces the time and cost involved in fulfilling mutual obligations. Offset also results in the mutual transfer of property. In this way, nothing can be said to have been misappropriated, or lost. This legal device is of considerable importance to banks, since most interbank transactions involve offsetting claims against each other. Shahidi, a prominent Iranian lawyer, defines offset as discharging two, or a set of debts two persons owe each other, to the least possible amount (Shahihi, 2011).

Clause 6 of Article 264 of the Iranian Civil Code considers confusion to be one of the causes of discharge of obligation, an issue to which Article 300 is devoted. In this Article (264), the legislators, however, failed to define the term "confusion." All they did was to merely indicate its qualities and conditions. Clause 6 of Article 264 was adopted from Clause 5 of Article 1234 of the French Civil Code, and, as mentioned above, is mentioned among the causes of discharge of obligation. The most common type of confusion is the case where an offspring is indebted to his father, who dies naturally, leaving the offspring as his only heir. In such a situation, the offspring will be the owner of all his deceased father's properties, including the debt he owed to his father. Therefore, confusion can be defined as integrating the two positions of creditor and debtor into one person regarding a debt. (Roudijani, 2011) In other words, confusion means a person's taking over possession of a debt to which he is obliged.

What is clear from the foregoing is that out of the six causes contained in Article 264 of the Iranian Civil Code, Iranian legislators have provided a definition only for discharge, and remained silent with regard to the other five causes. This is one of the problems presented by Article 264 because the failure to provide definitions for those causes creates ambiguities, and interpretive difficulty, leading to conflicting judicial judgments.

\subsubsection{Lack of Definition}

In written law, the importance of precise and accurate definitions for relevant concepts is obvious to clear sighted people. For example, mathematics begins with a series of definitions. Similarly, in life and empirical sciences, definitions play a significant role. Every science needs to yield a clear, specific and, as much as possible, comprehensive conception of what is being discussed, and to, at least, remove ambiguities. This is because the complication of suppositions restrains the proper understanding of the issues at stake. From time immemorial, providing exact definitions for relevant concepts has always received due consideration in all fields of knowledge. This has been underlined particularly in legal science. Since it is possible to have various 
viewpoints and ideas on a single matter, different definitions and descriptions may be presented. What is important, however, is firstly to illustrate our objective for defining different concepts. Typically, our main purpose is to present a completely perspicuous picture of the issue under consideration. This clear image helps to avoid the problem of diverse interpretations and impressions, and focuses the reader's minds in line with the intent of the writer.

As mentioned previously, one of the problems of Article 264 of the Iranian Civil Code is that Iranian legislators failed to define five of the six causes provided therein. That omission has resulted in conflicting commentaries, and made it difficult to understand the Article. In a bid to address this problem, the present authors propose the following definitions, which could be incorporated into the Civil Code in any future reforms:

1) Fulfillment of an obligation: it is the obligor acting in accordance with his obligation.

2) Cancellation of contract by mutual consent: it is the revocation of a contract to the satisfaction of both parties.

3) Release from an obligation: it is the creditor's voluntary waiver of his right.

4) Substitution of an obligation: it is the discharge of an obligation through the creation of another obligation.

5) Offset: it means the discharge of debts owed by debtors to each other.

6) Acquisition: it means the integration of the titles of debtor and creditor in one person for a debt.

\section{Conclusion}

In 1928, the late Davar completely transformed the Iranian legal system, bringing it closer in form to the French, Swiss and Belgian law. However, in terms of content, the Iranian legal system was aligned with Islamic law and Shia principles. Islamic law is one of the key features of Islam. This religion consists, on the one hand, of a set of public teachings determining the principles of the religion, and on the other, a part called Sharia, which determines what believers should or should not do. Sharia, literally meaning a path that should be followed, is what we call Islamic law.

The written law is one of the most important legal systems, dominating a large part of Europe, Central America, South America, as well as parts of Asia and Africa. Islamic law and Roman-Germanic law have had a considerable influence on the Iranian legal system. One of the reasons for the inclination towards the Roman-Germanic legal system in Islamic countries, including Iran, is the attachment to, and familiarity of these societies with Islamic law. Just like the Roman-Germanic law, Islamic law is codified and written, and despite some differences in nature, it has affinity with the Roman-Germanic legal system. Just as the Civil Code is considered to be the primary legal source under the Roman-Germanic legal system, so are the Quran and the Sunnah the principal sources of Islamic law.

Among the reasons why large parts of the Iranian Civil Code have been derived from French law is, in addition to political and cultural factors, the fact that the first Iranian lawyers pursued their studies in France. Furthermore, British law could not be translated and modelled, it being customary and non-written. Inevitably, Iranian legislators had to choose the type of law practised in those countries that had written and codified rules, and, of course, amongst them, Roman-Germanic law was the most outstanding. The Civil Code is the most important branch of private law, which determines and adjusts relationships among people in society without considering their social positions or titles.

Law is a world of rights, and obligations of people towards each other. Basically, the science of law addresses issues concerning the determination of the rights and obligations of individuals towards each other, and provides a method for creating such rights and obligations. Moreover, every legal system provides methods for the termination of the legal responsibility of an obligor, and his clearance from obligation. This is known as the means of obligation discharge. The discharge from contractual obligation is one of the important legal issues to which Articles 264 to 300 of the Iranian Civil Code are devoted.

Most parts of the Iranian Civil Code are, in structural form, an imitation of the French Civil Code. However, in terms of content, the Code has been adapted to Islamic law. In Islamic law, issues concerning obligation discharge are not classified separately. Instead, such issues are to be extracted from several different parts of Sharia relating to sale, debt, mortgage, incapacity, civil liability, draft, bail, donation, marriage, divorce, will, and so on. Under Article 264 of the Iranian Civil Code, an obligation may be discharged in one of the following ways: (i) fulfilment of obligation; (ii) cancellation of a contract by mutual consent; (iii) release from obligation: (iv) substitution of obligation; (v) offset and recoupment; and (vi) acquisition of debt.

The act of the Iranian legislators in providing for only six causes of discharge of obligation has led some reputed jurists to blindly adopt the same classification in their writings without any critical reflection. For example, those 
jurists fail to point out the fact that there are other possible causes of discharge of obligation that could be added to Article 264 of the Iranian Civil Code, such as lapse of time and revocation. As mentioned earlier, Iranian legislators provided for only six causes for the discharge of obligation, unlike the French Civil Code, which, in Article 1234, lists nine causes for the discharge of obligation.

The most important part of the Iranian Civil Code is that relating to the law of obligation, which its drafters extracted from the chapters dwelling on contracts and obligations in the French Civil Code. Some members of the commission charged with writing the Iranian Civil Code, who had studied legal science in Europe, simply translated the provisions of the French Civil Code, and delivered same to other members, who were Islamic jurists and legal scientists. The latter, in turn, modified the translated French provisions, in order to bring them in line with Islamic jurisprudence and Shitte principles. Evidently, the compilation and underlying research were not without inadequacies and outright errors. Nonetheless, the drafters' art and skill in combining elements of both systems of law is obvious in the Iranian Civil Code.

Following the successful constitutional revolution of 1906, Iranian legislators turned to Western law, especially French law, because of political, cultural and legal reasons. Hence, the modern Iranian legal system has the influence of both Islamic law and Roman Germanic law. In 1926, the Qajar dynasty was overthrown in the Kingdom of Iran, and Reza Shah was enthroned as the new King. He was not an educated man, but because of the new developments, and especially the emergence of a better informed society, he was forced to reform parts of the traditional system of governance in the country. His key reform was greater reliance on the new intelligentsia. A prominent member of the educated elite was Ali Akbar Davar, who had studied in the West, and was quite familiar with their legal system. He became responsible for the establishment of the new Iranian legal system.

The dominant thought of the Reza Shah regime was secularism. Their aim was to create a society akin to what existed in the West, with nationalism as its ideological basis. However, because of the strong Islamic legal structure then exiting, as well as its long history, the commission appointed to draft the Iranian Civil Code was inevitably composed of both Western educated, and Islamic legal scientists. The commission made efforts to adapt the Iranian Civil Code, as much as possible, to Islamic tenets. However, their attempt to forge a new form of law dictated by the needs of modernism, and with contents adopted from Belgian, Swiss, but especially, French law, inevitably resulted in some problems, as can be seen in Article 264 of the Iranian Civil Code.

The drafters of the Iranian Civil Code, in extracting Article 1234 of the French Civil Code, provided for only six causes of discharge of obligation under Iranian law, a subject to which Articles 264 to 300 were assigned. But, by doing so, the drafters have, in fact, transplanted the defects found in the French Civil Code, not only in form, but also in content. This was because of their failure to recognise the difference between the concepts of contract and obligation. And that has created some difficulties with respect to those Articles. Conflating the two concepts of contract, and obligation; deeming the alteration of obligation and cancellation of a contract by mutual consent as causes of discharge of obligation; the failure to provide relevant definitions in five out of the six causes in Article 264 , and the resulting ambiguities; as well as the worthlessness of the acquisition of debt in practice, have all been identified as problems.

Based on the foregoing examination of the causes of discharge of obligation, the following ambiguities can be identified. First of all, the fulfilment of obligation is the most usual way of discharging obligations. Articles 265 to 282, that is, 18 Articles of the Iranian Civil Code dwell on this issue. However, they fail to provide any definition for the fulfilment of obligation, neither has the condition for this legal act been declared explicitly. Second, discharge of obligation is an indirect result of the fulfilment of obligation, and not a direct cause of discharge of obligation as the Iranian legislators tend to believe.

The cancellation of a contract by mutual consent is an agreement to cancel a contract, which is one of the indirect causes for the discharge of obligation. This is because the cancellation of a contract by mutual consent is the cause of the dissolution of the contract, following which the obligation will be discharged. The cause of discharge of obligation must be indirect, not direct. The Iranian legislators have introduced release as one of the causes for the discharge of obligation, dedicating Articles 1128 to 1288 of the Civil Code to this issue. They defined release as when a creditor relinquishes his right out of his own will. It seems that such a definition is not a precise one because it does not clearly differentiate release from donation, another legal contract.

Substitution of obligation is the act of replacing one obligation with another one. The Iranian Civil Code explains the rules for the substitution of an obligation in Articles 292 to 293, just as the French Civil Code dedicates Articles 1271 to 1281 to the same issue. However, Iranian legislators, unlike their French counterparts, did not define the substitution of obligation, and this causes conflicting interpretations. Moreover, the adoption 
of only 2 out of the 10 Articles of the French Civil Code addressing the substitution of obligation has caused some ambiguities in the said Article 292 and 293 of the Iranian Civil Code. Perhaps, efforts in the field of comparative law could help to clarify such ambiguities.

The resulting ambiguities can be summarised as follows. Is the substitution of an obligation a superficial act, or substantive one? Is the substitution of an obligation a contract, or not? Does the changing of the time or place for the performance of an obligation, disturb the substitution of obligation? During the substitution of obligation, what form should the underlying guarantee (endorsement) take? Owing to the ambiguities present in Articles 292 and 293 of the Iranian Civil Code, the answers to these questions are sometimes conflicting. Therefore, efforts to clarify those ambiguities would be helpful in enhancing legal understanding. In Articles 294 to 299 of the Iranian Civil Code, the issue of offset is addressed. But no definition is provided for that term. Furthermore, some lawyers consider offset to be the fulfilment of an obligation, and not the discharge of an obligation. This is because by losing a right exercisable against each other, the parties have obtained the same value, and reduced the burden of their obligation.

Article 300 of the Iranian Civil Code states that if a debtor becomes the owner of what he owes, his liability ends. Thus, if anyone is a debtor to his ancestor, the debt is settled after the death of the said ancestor to the extent of the portion of inheritance to which the said debtor is entitled. With regard to this Article, considering the fact that the Iranian Civil Code, as well as its French equivalent considers this to be the discharge of obligation, there will be some ambiguities as follows: combining the titles of a debtor and a creditor in one person is logically impossible since the notion of obligation implicates two parties. Furthermore, Article 300, which was simply copied from the French Civil Code, can be said to be redundant because no case has arisen in this respect as far as Iranian case law is concerned. That provision, therefore, seems irrelevant to the Iranian society.

The improper combination of Islamic law and the French Civil Code, wrong classifications, and the failure to define key terms have led to ambiguities in Articles 264 to 300 of the Iranian Civil Code, as have been examined in this article. Because these Articles have not defined the causes of discharge of obligation comprehensively, an effort has been made in this article to highlight the resulting ambiguities, and to have them clarified through the provision of clear definitions.

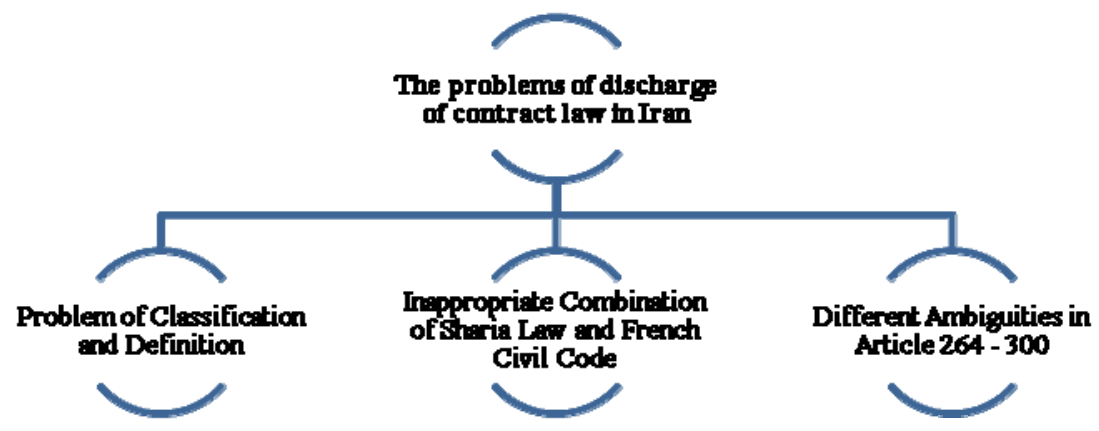

Figure 1. Problems arising from article 264 of the Iranian civil code

\section{Acknowledgements}

We would like to thank the Faculty of Law in Universiti Kebangsaan Malaysia (UKM) for their helpful advice and guidance during conducting this research.

\section{References}

Ahmadi, H. (2008). The Legal Nature of Performance of Obligation. Tehran Bar Association Journal, (8-9), 235 .

Aliabadi, A. (2009). The Development and Discharge of Obligations in Islamic Law (1st ed.). Daneshpazir Publications, Tehran.

Bagheri, A. (2003). Discharge of Obligation: Analytical Review of the Jurisprudence Principles of Civil Code (1st ed.). Nashr Publications, Tehran.

Bahrami Ahmadi, H. ( 2007). Generalities of Contracts (2nd ed.). Mizan Publications, Tehran. 
Bonakdar, M. (2005). The Civil Code (Vol. 1, 1st ed.). Espadan Publications, Tehran.

Collins, H. (2008). The European Civil Code the Way Forward (1st ed.). New York: Cambridge University Press. http://dx.doi.org/10.1017/CBO9780511620010

Eftekhari, J. (2005). An Overview of Contracts and Obligations Law (Vol. 1). Mizan Publications, Tehran.

Ghasemzadeh, S. M. (2008). The Principles of Contracts and Obligations, Theoretical and Applied (10th ed.). Dadgostar, Tehran.

Hamitivaghef, A. (2009). Principles of Contracts and Unilateral Obligations (1st ed.). Daneshnegar, Tehran.

Harisinejad, K. (2009, Summer). A Contemplation in Iranian Modern Law Effectiveness from the Roman-German Legal System. Legal Journal of Political Science Faculty, 39(2).

Hashemi, M. S. (2004). Jurisprudence Dictionary (1st ed.). Institution of Islamic Jurisprudence Encyclopaedia, Qom.

Jafari Langroudi, J. (2010). Obligations Law (4th ed.). Ganje-Danesh Publications, Tehran.

Javan-arasteh, H. (2009). Social and Political Law in Islam (5th ed.). Maaref Publications, Tehran.

Katouzian, N. (1997). The Position of Islamic Law. Tehran University Political Science Faculty Magazine, 26 , 105.

Katouzian, N. (2006). Civil Code, General Theory of Obligations (3rd ed.). Mizan Publications, Tehran.

Katouzian, N. (2008). General Principles of Contact (4th ed.). Mizan Publications, Tehran.

Katozian, N. (1998). Studying Iranian Legal System (18th ed.). Borna, Tehran.

Madani, S. J. (2004). Civil Liability of Delictual Liability (1st ed.). Paidar Publications, Tehran.

Mirzaee, A. (2009). Persian and English Civil Code (1st ed.). Behnam Publications, Tehran.

Nouri, M. A. (2001). Contracts and Obligations in French Civil Law (1st ed.). Ganje-Danesh Publications, Tehran.

Nouri, M. A. (2002). Egyptian Law (1st ed.). (Art. 371 Civil Code) and French Law (Art, 1272 Civil Code) Ganje-Danesh Publications, Tehran.

Roudijani, M. M. (2011). Discharge of Obligation (1st ed.). Ava Publications, Tehran.

Sadeghi, M. (2005). A Critique on the Causes of Discharge of Obligation in the Civil Code of Iran. Center for Notary Public.

Safaei, H. (2008). Introductory Course in Civil Code (6th ed.). Mizan Publications, Tehran.

Shahidi, M. (2008). Formation of Contracts and Obligations (7th ed.). Majd Publications, Tehran.

Shahidi, M. (2011). Discharge of Obligation (10th ed.). Majd Publications, Tehran.

Shiravi, A. (2010). Comparative Law (8th ed.). Samt Publications, Tehran.

Yaqin, A. (2007). Legal Research and Writing (1st ed.). Lexis Nexis Publications, Malaysia.

Zarini, H. H. (2009). Contemporary History of Iranian Judicial System and its Changes (1st ed.). Tehran Publications, Tehran.

\section{Note}

Note 1. Contract, like many other words, has been defined literally.

\section{Copyrights}

Copyright for this article is retained by the author(s), with first publication rights granted to the journal.

This is an open-access article distributed under the terms and conditions of the Creative Commons Attribution license (http://creativecommons.org/licenses/by/3.0/). 